\title{
Pemetaan Distribusi Petir Untuk Wilayah Manado Tahun 2013 Dan 2014
}

\author{
Michelle Jenneth Mailoora, Guntur Pasaua*, Maria D. Bobantoa* \\ aJurusan Fisika, FMIPA, Unsrat, Manado
}

K A T A K U N C

Pemetaan, Petir, Manado

\begin{abstract}
A B S T R A K
Telah dilakukan penelitian untuk memetakan distribusi petir untuk wilayah Manado berdasarkan data petir tahun 2013 dan 2014. Data real time sambaran petir dari rekaman lightning detector diolah menggunakan beberapa program, yaitu Lightning 2000, Golden Software Surfer 8, Lightning Data Processing, GIS 10.3, Google Earth dan Microsoft Excel. Pada program GIS 10.3 data yang didapatkan kemudian dipetakan menggunakan metode Kriging. Hasil yang diperoleh dalam penelitian ini berupa peta kontur distribusi petir di wilayah Kota Manado. Berdasarkan hasil dari pengolahan data, diperoleh data yang menunjukkan bahwa kejadian petir tertinggi terdapat pada bulan Oktober 2013 yaitu sebanyak 6.540 kejadian dan bulan Mei 2014 yaitu sebanyak 7.330 kejadian petir. Distribusi petir CG+ tertinggi terdapat pada kecamatan Wenang dan tidak ada kejadian petir CG+ di 4 kecamatan yaitu Kecamatan Tikala, Paal Dua, Singkil dan Tuminting.

A B S T R A C T

Research has been done to make a distribution map for Manado area based on lightning data of year 2013 and 2014. The real time data of lightning strikes from lightning detector processed by using a few program that is Lightning 2000, Golden Software Surfer 8, Lightning Data Processing, GIS 10.3, Google Earth and Microsoft Excel. Data that we got from GIS 10.3 use for mapping with Kriging method. Output from this research is contour map in Manado city area. Based on output from processed data, we got data that the highest lightning event happened in October 2013 that is 6.540 event and in May 2014 that is 7.330 lightning event. Highest CG+ lightning distribution located in Wenang Districts and there is no CG+ lightning event in 4 districts which is Tikala, Paal Dua, Singkil and Tuminting Districts.
\end{abstract}

KE Y W OR D S

Mapping, Lightning, Manado
TERSEDIA ONLINE

01 Februari 2018

\section{Pendahuluan}

Petir merupakan gejala listrik alami dalam atmosfer bumi yang tidak dapat dicegah. Fenomena alam ini terjadi akibat lepasnya muatan listrik baik positif maupun negatif yang terdapat dalam awan. Salah satu jenis sambaran yang sering terjadi adalah sambaran cloud to ground (CG) yang dilaporkan sebagai penyebab umum atas kerusakan atau kecelakaan yang disebabkan oleh kejadian petir. Sambaran akan diawali oleh kanal muatan negatif, menuju kedaerah yang terinduksi positif, sambaran yang terjadi umumnya adalah sambaran muatan negatif dari awan ke tanah (Suzuki, 1981).
Kepulauan Indonesia terletak pada $7^{\circ} \mathrm{LU}-12^{\circ} \mathrm{LS}$ dan $94^{\circ} \mathrm{BT}-142^{\circ} \mathrm{BT}$. Termasuk daerah tropis dengan tingkat pemanasan dan kelembaban tinggi mengakibatkan potensi kejadian petir wilayah ini menjadi sangat tinggi dibanding dengan daerah sub tropis (Tjasyono, 2005). Berbagai peristiwa sambaran petir telah banyak terjadi di wilayah Indonesia salah satunya adalah Sulawesi Utara. Beberapa diantaranya tidak hanya menyebabkan kerusakan bangunan dan infrastruktur tetapi juga bahkan menimbulkan korban jiwa. Kerugian yang dialami akibat sambaran petir bisa secara langsung maupun tidak langsung. Di kota Manado sendiri belum pernah ada peristiwa sambaran petir yang menewaskan orang tapi tetap merugikan.

*Corresponding author: Jurusan Fisika FMIPA UNSRAT, Jl. Kampus Unsrat, Manado, Indonesia 95115; Email address: michellemailoor@yahoo.com Published by FMIPA UNSRAT (2018) 
Contohnya saja pemadaman listrik yang beberapa kali terjadi akibat sambaran petir pada gardu maupun jalur aliran listrik. Pada tanggal 3 November 2015 pemadaman listrik selama 16 jam lebih terjadi di wilayah Kairagi, Mapanget, dan sekitarnya karena gangguan yang disebabkan oleh sambaran petir pada arrester di beberapa lokasi gardu (Redaksi, 2015). Peristiwa ini sangat merugikan bagi masyarakat maupun pemerintah.

Mengingat penelitian terkait sambaran petir di Manado belum banyak dilakukan dan besarnya bahaya serta kerugian yang dapat disebabkan oleh sambaran petir, maka diperlukan informasi terkait kejadian petir di daerah Manado. Oleh karena itu diperlukan pemetaan distribusi petir agar dapat menjadi bahan pertimbangan untuk mengurangi bahkan mencegah kerugian yang dapat diakibatkan oleh sambaran petir.

\section{Material dan Metode}

Penelitian ini dilaksanakan di Laboratorium Geofisika Jurusan Fisika Fakultas Matematika dan IImu Pengetahuan Alam Universitas Sam Ratulangi dan Badan Meteorologi, Klimatologi dan Geofisika Manado pada tahun 2017. Bahan yang digunakan adalah data petir tahun 2013 - 2014 dari BMKG Manado dan peta letak geografis Manado. Alat yang digunakan adalah software Lightning 2000, Golden Software Surfer 8, Lightning Data Processing, GIS 10.3, Google Earth, Microsoft Excel dan Microsoft Word.

\section{Hasil dan Pembahasan \\ Pemetaan distribusi petir wilayah Manado}

Data kejadian listrik udara yang telah diolah memuat informasi terkait waktu dan lokasi kejadian serta jenis sambaran petir yang terjadi. Dari data yang diperoleh kemudian disajikan dalam tabel kejadian petir per bulan untuk tahun 2013 dan 2014 (Tabel 1).

Tabel 1. Kejadian Petir Tahun 2013 dan 2014

\begin{tabular}{|l|c|c|l|}
\hline \multirow{2}{*}{ Bulan } & \multicolumn{2}{|c|}{$\begin{array}{c}\text { Jumlah } \\
\text { Kejadian } \\
\text { Petir (Tahun) }\end{array}$} & \multirow{2}{*}{ Ket } \\
\cline { 2 - 3 } & 2013 & 2014 & \\
\hline Januari & 1383 & 3313 & \\
\hline Februari & 561 & 864 & \\
\hline Maret & 1022 & 2051 & \\
\hline April & 2468 & 1480 & \\
\hline Mei & 4184 & 7337 & \\
\hline \multirow{2}{*}{ Juni } & 1714 & & Data bulan Juni \\
& 1502 & 406 & \\
\hline Juli & 15014 \\
\hline Agustus & 1993 & 2701 & \\
\hline September & 1340 & 1042 & \\
\hline Oktober & 6540 & 866 & \\
\hline November & 2053 & 3910 & \\
\hline Desember & 1131 & 1848 & \\
\hline
\end{tabular}

Pada tabel 1 bisa dilihat bahwa tidak ada data pada bulan Juni 2014. Hal ini disebabkan karena data .CSV bulan Juni 2014 yang telah diolah sebelumnya dari data yang diperoleh dari BMKG mengalami error. Data pada tabel 1 kemudian dibuat grafik kejadian petir untuk tiap tahunnya yaitu tahun 2013 (Gambar 1) dan 2014 dan (Gambar 2).

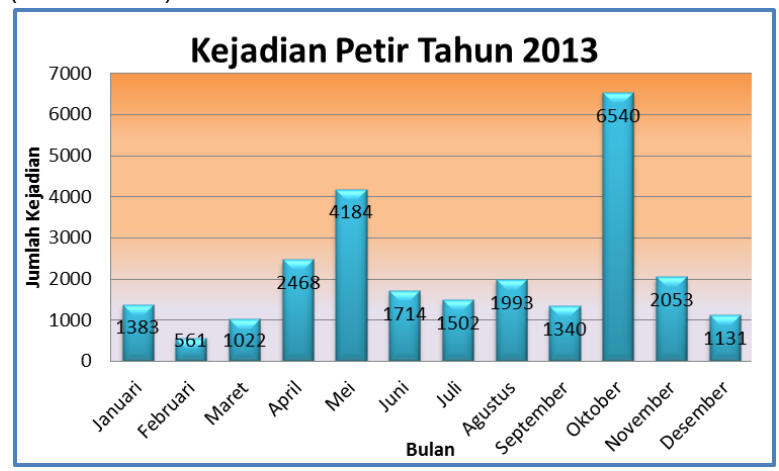

Gambar 1. Grafik Kejadian Petir Tahun 2013

Dari grafik kejadian petir tahun 2013 (Gambar 1) bisa diamati bahwa pada tahun 2013, kejadian petir tertinggi terjadi pada bulan Oktober yaitu sebanyak 6.540 kejadian dan terendah pada bulan Februari yaitu 561 kejadian.

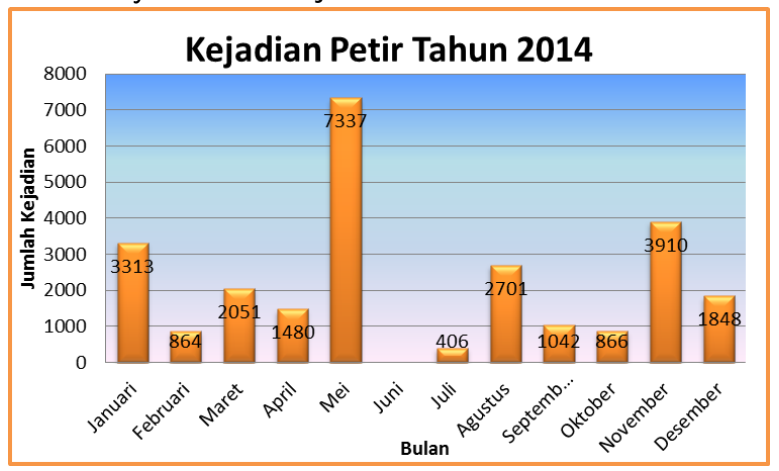

Gambar 2. Grafik Kejadian Petir Tahun 2014

Dalam gambar 2 telah ditunjukkan bahwa pada tahun 2014, kejadian petir tertinggi terdapat pada bulan Mei yaitu sebanyak 7.337 kejadian dan terendah pada bulan Juli yaitu 406 kejadian.

Aktifitas petir mengalami peningkatan dari musim panas ke musim hujan dan terus meningkat selama masa peralihan (Albrecht et al, 2007). Tingginya kejadian petir pada bulan Oktober 2013 dan Mei 2014 disebabkan karena masa tersebut merupakan masa peralihan musim atau pancaroba.

Data yang digunakan adalah data kejadian petir dalam wilayah $1,40^{\circ}-1,63^{\circ} \mathrm{LU}$ dan $124,67^{\circ}$ $124,91^{\circ}$ BT per hari. Lalu data tersebut dikompilasikan per bulan dan per tahun. Data ini kemudian dipetakan dalam bentuk kontur sebaran distribusi kejadian petir per tahun.

Metode interpolasi yang digunakan dalam proses pemetaan adalah metode kriging. Metode ini digunakan karena dapat memetakan distribusi kejadian petir secara lebih detail karena menggunakan kombinasi linear dari weight untuk memperkirakan nilai di antara sampel data 
(Pramono, 2008). Peta sebaran distribusi kejadian petir selama tahun 2013 dan 2014 tersaji pada gambar 3 dan gambar 4.

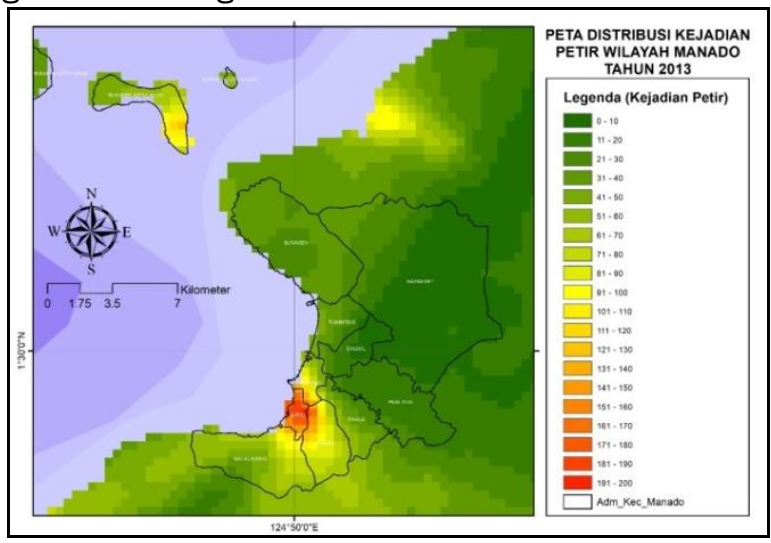

Gambar 3. Peta Distribusi Petir Wilayah Manado Tahun 2013

Pada Tahun 2014, distribusi kejadian petir di Kota Manado relatif sama dengan tahun 2013 dimana kejadian petir tertinggi terdapat di Kecamatan Sario dan kejadian petir terendah terdapat di Kecamatan Mapanget.

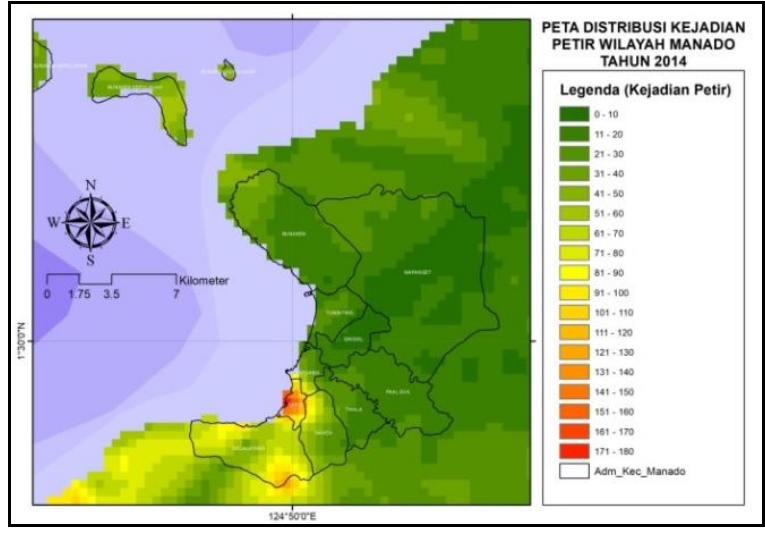

Gambar 4. Peta Distribusi Petir Wilayah Manado Tahun 2014

Pada kecamatan lainnya seperti kecamatan Tikala, Paal Dua, Singkil, Tuminting, Mapanget, Bunaken serta Bunaken Kepulauan, kejadian listrik udara tergolong rendah karena daerah ini banyak yang merupakan daerah pemukiman sementara yang lain masih berupa hutan. Berbeda dengan sebelumnya, kecamatan Malalayang pada tahun 2014 menunjukkan kejadian listrik udara yang cenderung tinggi, hal ini mungkin disebabkan karena daerah ini mempunyai banyak perbukitan sehingga memungkinkan terjadinya awan petir yang meningkatkan kejadian listrik di udara.

Jika dibandingkan kedua gambar ini (Gambar 3 dan gambar 4), keduanya menunjukkan hal yang sama yaitu kejadian listrik udara tertinggi terdapat pada kecamatan Sario. Daerah di sekitarnya seperti kecamatan Wenang dan Wanea juga mengalami kejadian listrik udara yang tinggi. Kejadian petir yang tinggi di Kecamatan Sario dan sekitarnya sangat erat kaitannya dengan sebaran bangunan tinggi di kawasan reklamasi Teluk Manado yang merupakan pusat perekonomian dan perdagangan di Kota Manado. Petir cenderung menyambar objek yang memiliki permukaan yang lebih tinggi dari sekitarnya seperti bangunan tinggi dan gedung BTS. Hal ini disebabkan kuat medan di sekitar ujung / puncak bangunan tersebut lebih rapat dan sifat dari muatan cenderung berkumpul pada tepian tepian runcing pada bangunan. Hal ini kontras dengan kejadian petir yang rendah di Kecamatan Mapanget dimana kepadatan bangunan disana sangat rendah. Peta sebaran bangunan di Kota Manado secara umum tersaji pada gambar 5 .

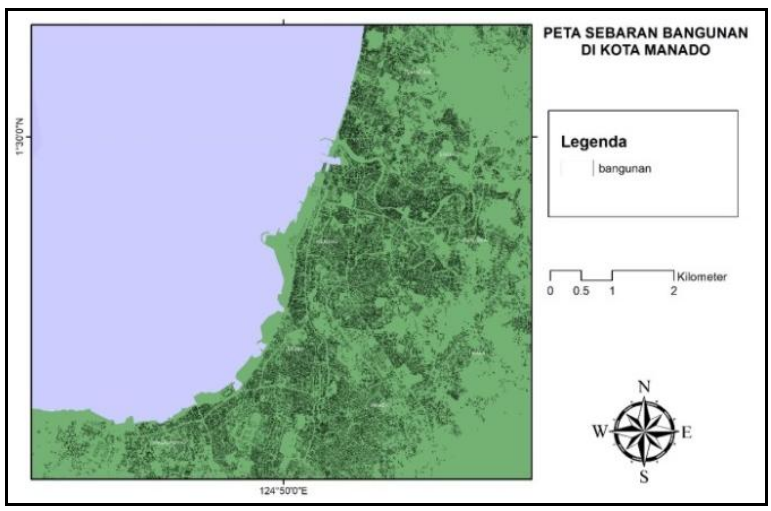

Gambar 5. Peta Sebaran Bangunan di Kota Manado (Sumber: BMKG)

Gambar 3 dan gambar 4 memuat seluruh kejadian listrik udara seperti Intercloud (IC), Cloud to Cloud (CC) maupun Cloud to Ground (CG). Sementara diketahui jenis petir $C G$ adalah jenis paling destruktif. Sehingga dari peta tersebut belum bisa ditentukan secara pasti daerah yang perlu diwaspadai untuk terjadinya sambaran petir.

\section{Pemetaan distribusi petir CG+ wilayah Manado}

Jenis petir yang berbahaya dan dapat menimbulkan kerusakan adalah adalah jenis petir CG+. Yaitu terjadinya pelepasan ion positif dari awan ke bumi. Petir jenis CG inilah yang paling berbahaya karena memberikan efek langsung terhadap kehidupan makhluk hidup. Sambaran petir CG dapat langsung mengenai manusia, hewan maupun tumbuhan di permukaan bumi, selain itu juga dapat mengenai saluran-saluran listrik, tower, dan dapat menggangu langsung pada barang barang elektronik (Jihad dan Sania, 2015).

Peta yang disajikan sebelumnya dianggap belum dapat menunjukkan tingkat bahaya petir, maka perlu dibuat peta sebaran kejadian listrik udara tipe $C G$ positif $(C G+)$. Untuk membuat peta tersebut, terlebih dahulu dilakukan penyortiran data. Setelah proses penyortiran dilakukan data ini kemudian dipetakan. Kejadian petir $C G+$ per bulan ditunjukkan pada Gambar 6. 


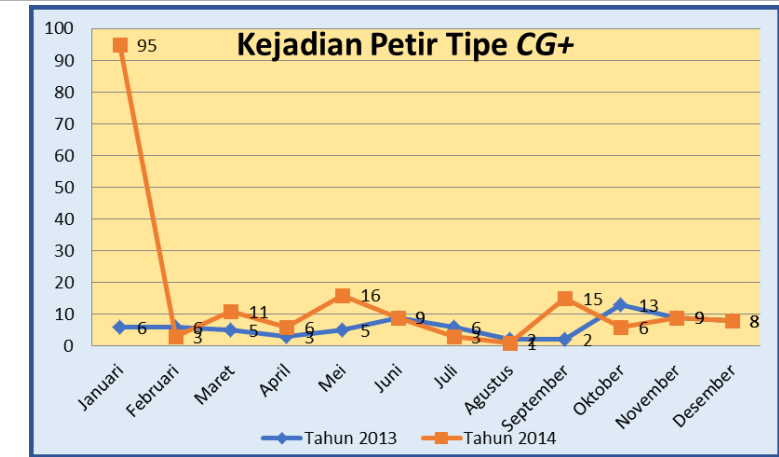

Gambar 6. Grafik Petir Tipe CG+ Tahun 2013 dan 2014

Dari gambar 6 dapat dilihat bahwa frekuensi kejadian petir tertinggi tahun 2013 terdapat pada bulan Oktober sedangkan pada tahun 2014, frekuensi kejadian petir tertinggi terdapat pada bulan Januari.

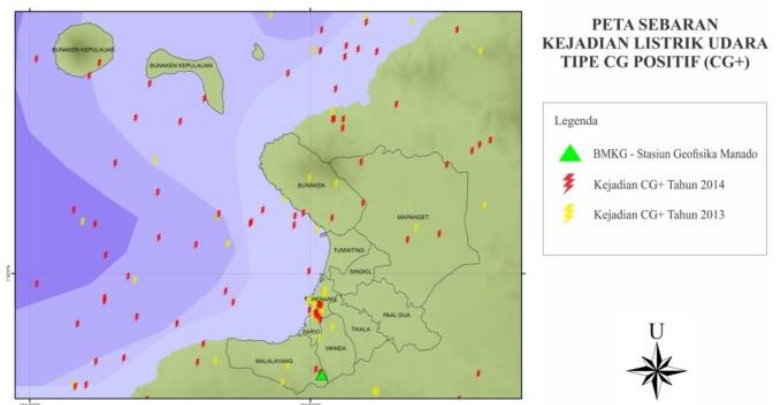

Gambar 7. Peta sebaran kejadian listrik udara tipe CG Positif $(C G+)$

Peta distribusi kejadian petir CG+ di daerah Manado ditampilkan pada Gambar 7. Gambar ini menunjukkan bahwa daerah paling rawan terjadinya sambaran petir terdapat pada kecamatan Wenang. Mengacu pada sifat petir yang menyambar benda yang lebih tinggi (Gunawan dan Pandiangan, 2014), maka diperkirakan tingginya sambaran petir CG+ di wilayah ini disebabkan karena wilayah ini padat akan pembangunan dan mempunyai banyak gedung-gedung tinggi dan serta tower yang menjadi pemicu terjadinya sambaran petir. Namun hal ini perlu diteliti lebih jauh terkait seberapa besar gedung tinggi dapat meningkatkan frekuensi sambaran petir. Berdasarkan gambar 6, ada beberapa kecamatan yang tidak terdapat kejadian petir tipe CG Positif (CG+) seperti kecamatan Tikala, Paal 2, Singkil dan Tuminting.

\section{Kesimpulan}

Dari hasil penelitian dan pembahasan yang telah dilakukan, dapat disimpulkan bahwa :

1. Kejadian petir tertinggi terdapat pada bulan Oktober 2013 yaitu sebanyak 6.540 kejadian dan bulan Mei 2014 yaitu sebanyak 7.330 kejadian petir.

2. Distribusi petir CG+ tertinggi di kota Manado terdapat pada kecamatan Wenang. Dan tidak terdapat kejadian petir CG+ di 4 kecamatan yaitu Kecamatan Tikala, Paal Dua, Singkil dan Tuminting.
Daftar Pustaka

Albrecht, R,. Morales, C., Neves, J., Dias, M.A.S. 2007. Lightning Activity On Thunderstorm Relative To The Microphysics, Thermodynamics and Large-Scale Features In The Amazon Region. University Of Sao Paolo. Brazil.

Gunawan, T., dan Pandiangan, L.N.L. 2014. Analisis Tingkat Kerawanan Bahaya Sambaran Petir Dengan Metode Simple Additive Weighting Di Provinsi Bali. Balai Besar Meteorologi Klimatologi dan Geofisika Wilayah III. Denpasar.

Jihad, A., dan I.R. Sania. 2015. Identifikasi Pola Sambaran Petir Cloud To Ground (CG) Tahun 2014 Di Wilayah Provinsi Aceh. Geofisika. Aceh.

Pramono, G.H. 2008. Akurasi Metode IDW dan Kriging Untuk Interpolasi Sebaran Sedimen Tersuspensi. Bakosurtanal.

Redaksi. 2015. Listrik Mapanget Disambar Petir, Perbaikan Hingga Jam 6 Sore. http://www.gomanado.com/2015/11/03/928 4/listrik-mapanget-disambar-petir-perbaikanhingga-jam-6-sore/ [22 Oktober 2017].

Septiadi, D., Hadi, S., dan B. Tjasyono. 2011. Karakteristik Petir Dari Awan Ke Bumi Dan Hubungannya Dengan Curah Hujan. Jurnal Sains Dirgantara. (8)2: 129-138

Suzuki, T. 1981. Study on Experimental Simulation on Lightning Strokes. IEE Trans. On Power Apparatur and Systems, Vol. PAS-100, No. 4.

Tjasyono, B.HK. 2005. Sains Atmosfir. ITB Bandung. 